\title{
Corallivory in tubelip wrasses: diet, feeding and trophic importance
}

\author{
A. J. Cole* + + M. S. Pratchett* and G. P. Jones*† \\ *ARC Centre of Excellence for Coral Reef Studies, James Cook University, Townsville, \\ Queensland 4811, Australia and $†$ School of Marine and Tropical Biology, James Cook \\ University, Townsville, Queensland 4811, Australia
}

(Received 11 August 2008, Accepted 6 November 2009)

\begin{abstract}
This paper describes a 2 month study of the patterns of abundance, feeding pressure, diet and feeding selectivity in corallivorous tubelip wrasses (Labridae), rarely studied, yet widespread and abundant group of corallivores on Indo-Pacific coral reefs. The relative abundance and feeding pressure of corallivorous wrasses and butterflyfishes (Chaetodontidae) in Kimbe Bay, Papua New Guinea, were compared. Overall, tubelip wrasses were more than twice as abundant as corallivorous butterflyfishes and accounted for three times as many feeding bites on corals. The three most abundant tubelip wrasses (yellowtail tubelip Diproctacanthus xanthurus, Allen's tubelip Labropsis alleni and the tubelip wrasse Labrichthys unilineatus) were all obligate corallivores taking $>97 \%$ of bites from the surface of live corals. Labropsis alleni and D. xanthurus were highly selective, consuming preferred prey species in proportions significantly higher than expected given their availability. In contrast, $L$. unilineatus was fairly non-selective and consumed most corals in direct accordance with their availability. As coral predators, tubelip wrasses are highly comparable to coral-feeding butterflyfishes in the coral species consumed, range of dietary specialization and their reliance on live coral. Tubelip wrasses, however, may supersede butterflyfishes as the predominant corallivorous family in some Indo-Pacific locations, and coral-feeding tubelip wrasses are likely to be severely affected by coral decline.

Key words: Chaetodontidae; coral predator; selectivity; specialization.

\section{INTRODUCTION}

The ecological role of a species can only be interpreted from an understanding of its distribution, diet and patterns of feeding selectivity (Cox, 1986; Morrison, 1988; Jones, 1992; Bellwood, 1996; Rotjan \& Lewis, 2006; Ceccarelli, 2007; Hoey \& Bellwood, 2008). Likewise, the effect of ecologically similar species or guilds depends upon the pattern of abundance of guild members, the extent of their dietary specialization and the degree to which they partition habitats and food resources (Bellwood \& Choat, 1990; Fox \& Bellwood, 2007; Hoey \& Bellwood, 2008). These factors also have important implications for how species and guilds respond to changing or degrading environments. Highly specialized species are susceptible to declining

\$Author to whom correspondence should be addressed. Tel.: +61 747816058 ; fax: +61 74725 1570; email: Andrew.Cole3@jcu.edu.au 
resources (Reese, 1981; Kokita \& Nakazono, 2001; Halford et al., 2004; Jones et al., 2004; Munday, 2004; Pratchett et al., 2006; Feary, 2007), and a guild of specialists with highly overlapping resource requirements are especially susceptible to a loss of a restricted range of resources (Sano, 2004; Gardiner \& Jones, 2005).

On tropical reefs, coral-feeding fishes represent one of the most distinctive and most specialized functional groups of coral reef fishes (Randall, 1974). Corallivory is increasingly recognized as an important feeding mode that may affect the structure of coral reef habitats (Neudecker, 1979; Wellington, 1982; Cox, 1986; Rotjan et al., 2006; Pratchett, 2007). As a functional group, specialist corallivores are intricately linked to the corals on which they feed and are the first and worst affected group of reef fishes following major disturbances that result in coral mortality (Reese, 1981; Sano, 2004; Graham et al., 2006, 2009; Wilson et al., 2006). Furthermore, the loss of these corallivores from reef assemblages has important flow-on effects for higher trophic levels; the primary production provided by zooxanthellate corals will be effectively lost from coral-reef food webs (Glynn, 2004). The taxonomic extent of corallivory and the variation in the degree of dietary specialization and overlap has only recently been appreciated (Cole et al., 2008; Rotjan \& Lewis, 2006, 2008). Coral-feeding fishes are taxonomically diverse and have been recognized in at least 11 reef-fish families (Cole et al., 2008). Specific dietary composition, however, has been documented for relatively few species, primarily Chaetodon butterflyfishes (Irons, 1989; Cox, 1994; Alwany et al., 2003; Berumen et al., 2005; Pratchett, 2005; Graham, 2007). Very little research has been conducted on coral-feeding species from other major families, such as the Tetradontidae, Monacanthidae, Pomacentridae and Labridae, and the extent of dietary specialization and overlap is unknown. The abundance of these other corallivores relative to the more widely studied butterflyfishes (Chaetodontidae) has also seldom been investigated.

The majority of research on corallivory to date has focused on butterflyfishes where it is unusually prevalent and well recognized. Numerous studies across wide geographical ranges have allowed generalizations to be drawn about species-specific behaviour (Birkeland \& Neudecker, 1981; Gore, 1984; Cox, 1994; Pratchett, 2005; Graham, 2007; Pratchett \& Berumen, 2008). For example, despite high diversity of corals on most reefs (often $>150$ species), many butterflyfishes tend to feed on a very specific sub-set of available corals (Irons, 1989; Alwany et al., 2003; Berumen et al., 2005; Pratchett, 2005, 2007; Graham, 2007). Even the most generalist coralfeeding butterflyfish, the redfin butterflyfish Chaetodon lunulatus Quoy \& Gaimard, eats $<30 \%$ of available coral species (Pratchett et al., 2004). Moreover, there is very high concordance in feeding preferences of coral-feeding butterflyfishes. In the northern Great Barrier Reef, Pratchett (2007) showed that virtually all corallivorous butterflyfishes (11 of 14 species) feed predominantly on either Acropora hyacinthus or Pocillopora damicornis. Selective feeding on a small number of coral species has important implications for the composition of both coral communities and fish assemblages (Cole et al., 2008). For example, the highly preferred P. damicornis is restricted to shallow lagoons in Guam due to the high levels of predation on the reef slope (Neudecker, 1977, 1979). Conversely, declines in preferred coral species can lead to decreased physiological condition (Pratchett et al., 2004; Berumen et al., 2005) and even the localized extinction of corallivorous fishes (Reese, 1981; Kokita \& Nakazono, 2001; Wilson et al., 2006). These same conclusions, however, cannot be extrapolated to non-chaetodontid corallivores without first investigating individual 
species or genera. Each new corallivorous group represents a unique evolutionary path. As such, these under-studied taxa require detailed dietary and behavioural studies before their relative importance to corallivory can be ascertained. These studies can then be compared with the existing chaetodontid-focused literature to make broader assumptions about the implications of fish predation on corals.

There are several reasons why generalizations about butterflyfishes may not apply to other taxa. Butterflyfishes have fairly distinct feeding behaviour, visually locating and feeding from exposed tentacles of individual polyps, and they derive nutrition mainly from coral tissue (Reese, 1977; Tricas, 1989; Aeby, 2002; Gochfeld, 2004). Corallivorous wrasses, on the other hand, may derive most of their nutrition from coral mucus, rather than the tissue itself. For example, McIlwain \& Jones (1997) showed that the tubelip wrasse Labrichthys unilineatus (Guichenot) preferentially fed from injured and damaged coral colonies over healthy, intact coral, which, they hypothesized, may be due to increased mucous production and release of olfactory cues by injured colonies. If coral-feeding wrasses feed mostly on coral mucus, it is likely that their patterns of prey preference would be fundamentally different to that of other coral-feeders, targeting those species with highest mucous production.

The role of corallivores can only be interpreted from fundamental information on abundance, feeding pressure, diet and feeding selectivity. The aims of this study were: 1) to examine the distribution and abundance of corallivorous wrasses and compare their relative contribution to corallivory with butterflyfishes and 2) to quantify dietary composition and feeding selectivity for the three most abundant and widespread species of tubelip wrasse, yellowtail tubelip Diproctacanthus xanthurus (Bleeker), L. unilineatus and Allen's tubelip Labropsis alleni Randall. The level of specialization and reliance on coral of corallivorous wrasse was compared with the dietary specialization with published information on butterflyfishes to identify whether coral-feeding wrasses are functionally similar to butterflyfishes.

\section{MATERIALS AND METHODS}

Fieldwork was conducted over a 2 month period between October and December 2006 in Kimbe Bay, on the island of New Britain, Papua New Guinea $\left(5^{\circ} 25^{\prime} \mathrm{S} ; 150^{\circ} 05^{\prime} \mathrm{E}\right)$. Although little studied, this region is typical of the coral triangle region in terms of the representation of corallivorous fishes (Allen \& Munday, 1994). This region experienced a steady decline in coral cover from 66\% in 1996 to as low as 7\% in 2002 (Jones et al., 2004); coral cover has been increasing since then and is currently at 30-40\% (unpubl. data). Research focused on three sheltered inshore platform reefs typical of the bay: Matane Walindi, Luba Luba and Hanging Gardens. All three reefs are isolated platform reefs with steep slopes and shallow reef tops, located $<1 \mathrm{~km}$ from the mainland island of New Britain. The maximum distance between reefs is $c .600 \mathrm{~m}$, although they are separated by very deep water (c. $180 \mathrm{~m}$ ) (Holthus, 1994; Holthus \& Maragos, 1994). The three reefs were selected for their similarity in size, shape and proximity to the shoreline, and for the purposes of this study were considered one homogenous near-shore reef.

\section{CORALLIVORE ABUNDANCE AND CONTRIBUTION TO CORALLIVORY}

Abundances of corallivorous fishes were quantified at four distinct depths: 0, 2, 6 and $10 \mathrm{~m}$ below the reef crest. At each depth, the abundance of all corallivorous fishes was quantified along replicate $50 \mathrm{~m} \times 4 \mathrm{~m}$ belt transects (following Jones et al., 2004). Four 
replicate transects were run within each depth zone, laid from haphazardly selected starting points and following depth contours of the reef. The observer waited c. 5 min after deploying the transect line to allow the fishes to resume their normal behaviour. Subsequently, one diver swam along the transects and recorded all corallivorous fishes encountered $2 \mathrm{~m}$ either side of the tape (following Khalaf \& Abdallah, 2005); to eliminate any bias, all counts were performed by the same observer. The near-shore reefs of Kimbe Bay are relatively small platform reefs with steep sides and as such there is a large environmental difference over the $10 \mathrm{~m}$ depth range. By sampling a combined area of $800 \mathrm{~m}^{2}$ at each depth, the variation in fish communities that corresponded with this habitat gradient was adequately captured.

To compare and contrast the functional importance of different fishes as coral predators, in situ feeding observations were undertaken. Feeding observations of 15 min were conducted within 16 replicate $2 \mathrm{~m} \times 2 \mathrm{~m}$ quadrats established at each of four depths $(0,2,6$ and $10 \mathrm{~m}$ below the reef crest), corresponding with transect-based sampling. Each quadrat was positioned in areas with relatively high coral cover ( $>50 \%$ live coral), as the purpose of this study was to quantify relative rates of coral feeding by different fish species and not to extrapolate rates of feeding per unit area. During observations, the total number of bites taken by each corallivorous fish (L. unilineatus, D. xanthurus, L. alleni, southern tubelip Labropsis australlis Randall, eastern triangular butterflyfish Chaetodon baronessa Cuvier, eight-banded butterflyfish Chaetodon octofasciatus Bloch, C. lunulatus, Klein's butterflyfish Chaetodon kleinii Bloch and the chevroned butterflyfish Chaetodon trifascialis Quoy \& Gaimard) on any live coral within the quadrat area was recorded. Feeding observations were split evenly between the morning (0800-1200 hours) and afternoon (1200-1600 hours) periods, to reduce any confounding influence of diurnal feeding patterns. Moreover, all feeding observations were completed within a single 10 day period (13 to 23 October 2006).

\section{FEEDING OBSERVATIONS OF CORALLIVOROUS WRASSES}

Focal animal sampling with all occurrences was used to assess dietary composition of L. unilineatus, D. xanthurus and L. alleni; this sampling was conducted on 75-144 randomly selected individuals of each species on the exposed fore-reef slope and flat. Based on a pilot study (Cole, 2007), the optimal duration of observations was 4 min during which time each fish was followed at a distance of 1-3 m, while feeding behaviour and dietary composition were recorded. Observations were terminated if the individual disappeared from view or showed any noticeable signs of distress. Labrichthys unilineatus is sexually dimorphic, so feeding observations were performed equally (72 observations) on both sexes, but later pooled due to the high similarity. The sexes could not be discerned in either L. alleni or D. xanthurus. To account for any diurnal variation in feeding rates, approximately equal numbers of observations were conducted during three time periods: morning (0600-1000 hours), mid-day (1000-1400 hours) and afternoon (1400-1800 hours).

In addition to recording dietary composition, several other biological attributes were also recorded such as body size, group dynamics (e.g. paired and solitary) and interspecific and intraspecific aggression. Additionally, the condition of the substratum being fed from was also noted as either healthy or damaged. Damaged substratum consisted of broken, bleached or diseased corals, or colonies with conspicuous recent injuries. No account was taken of the potential causes (e.g. bleaching, sedimentation or crown-of-thorns starfish) of coral damage and injuries, but the proportion of coral colonies within these categories was generally low $(<10 \%)$.

Dietary overlap was assessed using Schoener's similarity index $(T)$ determined from $T=1-0.5 \sum\left|P x_{\mathrm{i}}-P y_{\mathrm{i}}\right|$, where $P x_{\mathrm{i}}$ and $P y_{\mathrm{i}}$ are the proportions of bites on each coral species for species pair $x, y$. $T$ ranges from 0 to 1 ; values $>0.6$ represent species that show very high similarity in diet and are not considered sustainable over ecological time due to the detrimental effects of direct competition over shared resources (Ross, 1986). Conversely, dietary overlap $<0.4$ indicates that there are major differences in patterns of prey use. 


\section{FEEDING SELECTIVITY OF CORALLIVOROUS WRASSEES}

Feeding selectivity of corallivorous wrasses were assessed by comparing the proportional use of coral consumed (estimated by the number of bites on each species) to their relative availability inside individual feeding territories or home ranges. To determine an individual's feeding range, each fish was followed, and the boundaries of its foraging areas marked with weighted flagging tape. Individual fishes were monitored for at least $30 \mathrm{~min}$; this area was then marked out by laying a measuring tape encompassing all previously marked edge boundaries. These territories were checked randomly throughout the day; if the fish could not be found inside the marked territory, the area was re-observed until the fish was found and its new boundaries were identified and marked.

When the fishes were consistently found foraging inside the marked-out area, feeding selectivity observations began the next day. Feeding observations of $10 \mathrm{~min}$, three times throughout the day, were used to assess feeding selectivity. These feeding observations were conducted in the same way as the 4 min observations; however, they provided a cumulative total of 30 min worth of feeding data per fish.

The availability of prey corals within each feeding territory was estimated using replicate line-point transects (Nadon \& Stirling, 2006). Transects were laid every $0.5 \mathrm{~m}$ along the longest side of an individual's territory, and the substratum was recorded every $10 \mathrm{~cm}$ along each transect. In this way, territories were effectively split up into a $10 \mathrm{~cm} \times 50 \mathrm{~cm}$ grid. This method was utilized for $D$. xanthurus and L. unilineatus and provided a direct comparison between an individual's diet and its diet choices. This method could not be used for L. alleni due to the deeper nature of its feeding ranges and the lack of well-defined foraging areas. For these reasons, L. alleni's dietary selectivity was examined in a broader manner, such that coral prey availability was assessed at the population level. Five $50 \mathrm{~m}$ transects were laid and the substratum recorded at $10 \mathrm{~cm}$ intervals, to provide a total of 2500 individual points. These transects were run parallel to the reef slope from a haphazardly selected starting point between a depth of 8 and $17 \mathrm{~m}$. The 4 min feeding observations of L. alleni at Matane Walindi were pooled and provided a total of 54 replicate feeding observations, which corresponded to the area in which the coral cover was sampled. This allowed a viable comparison between feeding and availability of coral prey.

Feeding selectivity for all species of corallivorous wrasses was analysed using the loglikelihood statistic $\left(\mathrm{X}^{2}{ }_{L 2}\right)$, calculated through the following formula: $\mathrm{X}_{L 2}^{2}=2 \sum_{j=1}^{n} \sum_{i=1}^{I}$ $u_{i j} \ln \left\{u_{i j}\left[E\left(u_{i j}\right)\right]^{-1}\right\}$, where $u_{i j}$ is the proportional use of each prey type $(i)$ by each individual $(j)$, and $E\left(u_{i j}\right)$ is the expected number of bites taken from prey type $i$ by the $j$ th individual if use is proportional to availability (Manly et al., 1993). Resource selection functions were then used to determine which coral species were consumed more or less frequently than expected (from their availability) by each species of wrasse. Bonferroni-corrected 95\% CI were calculated around each selection function. Use was deemed disproportionate (either positively or negatively) to availability if the $95 \%$ CI did not contain 1 (Manly et al., 1993).

\section{RESULTS}

\section{CORALLIVORE ABUNDANCE AND DISTRIBUTION}

A total of nine corallivorous butterflyfishes [C. baronessa, C. lunulatus, C. octofasciatus, ornate butterflyfish Chaetodon ornatissimus Cuvier, latticed butterflyfish Chaetodon rafflesi (Bennett), C. trifascialis, pennant bannerfish Heniochus chrysostomus Cuvier and the humphead bannerfish Heniochus varius (Cuvier)] and four tubelip wrasses (L. unilineatus, D. xanthurus, L. alleni and L. australis) were observed on the study reefs, although most of these species were rarely encountered. Tubelip wrasses were the most abundant corallivores across all depths and had an overall mean \pm S.E. density of $16.50 \pm 1.59$ fish per $200 \mathrm{~m}^{2}$, two and a half times higher than that found for the butterflyfish $\left(6 \cdot 50 \pm 0.83\right.$ per $\left.200 \mathrm{~m}^{2}\right)$. Labrichthys 


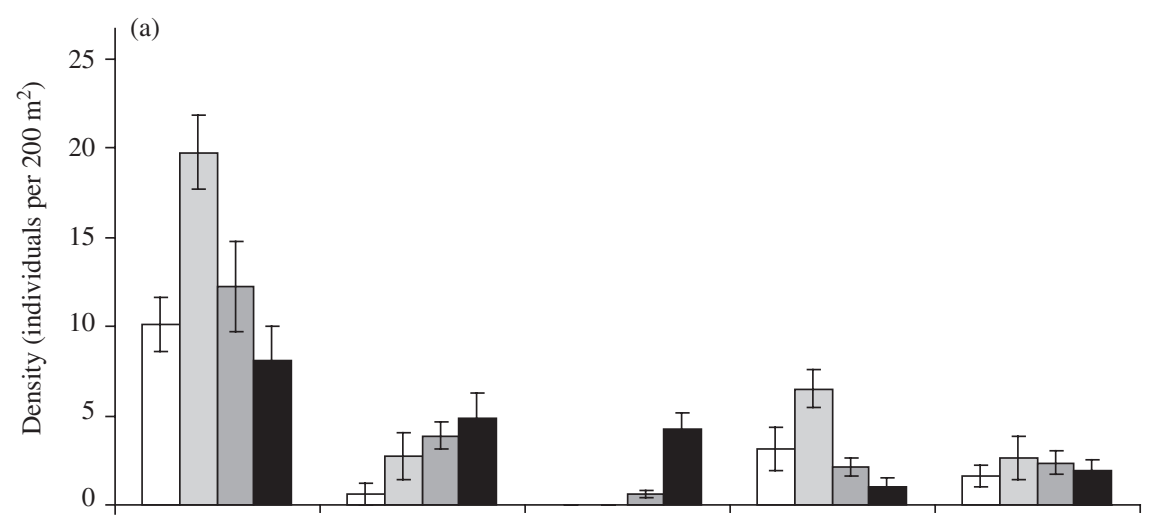

(b)

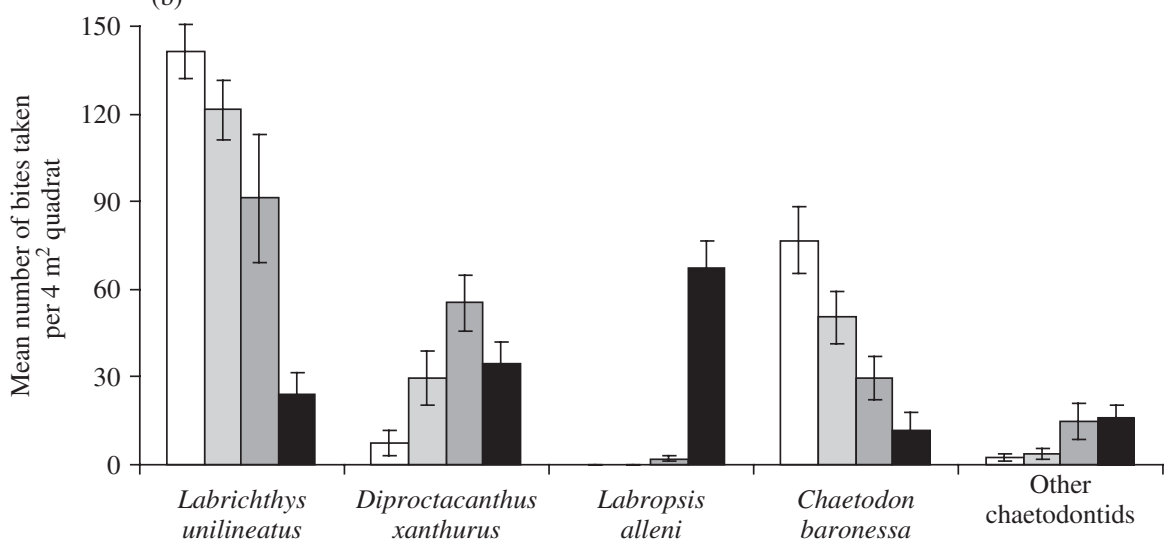

FIG. 1. Comparison of abundance and importance to corallivory of coral-feeding wrasses and butterflyfishes in Kimbe Bay. (a) Mean \pm S.E. density of the most common corallivorous species, observed across four depths ( $\square 0, \square 2, \square 6$ and $\square 10 \mathrm{~m}$ ) and (b) mean \pm s.E. number of bites taken in $4 \mathrm{~m}^{2}$ quadrats over $15 \mathrm{~min}$ by corallivorous fishes at four depths on near-shore reefs in Kimbe Bay.

unilineatus was by far the most abundant coral-feeding species across all depths. Densities peaked $2 \mathrm{~m}$ below the crest with $19.75 \pm 1.03$ individuals per $200 \mathrm{~m}^{2}$ (Fig. 1). Diproctacanthus xanthurus showed a trend of increasing in abundance with depth and the greatest densities occurred at the deepest zone $(10 \mathrm{~m})$ with $4.87 \pm$ 0.68 individuals per $200 \mathrm{~m}^{2}$. The remaining two tubelip wrasses, L. australis and L. alleni, were relatively rare and restricted to the deeper zones. Of these two species, L. alleni was more abundant with $4.25 \pm 1.11$ individuals per $200 \mathrm{~m}^{2}$ in the deepest zone.

Corallivorous butterflyfishes were much lower in abundance than tubelip wrasses. Only one species, $C$. baronessa, was present in any notable numbers, and abundances were highest in the shallows and declined with depth. The highest mean abundance for this species occurred at $2 \mathrm{~m}$ below the crest with densities of $6.50 \pm 0.53$ individuals per $200 \mathrm{~m}^{2}$ [Fig. 1(a)]. 


\section{CONTRIBUTION OF WRASSES AND BUTTERFLYFISHES TO CORALLIVORY}

Feeding observations conducted within the 64 quadrats yielded a total of 12447 bites on live scleractinian corals, which equate to a mean \pm S.E. feeding rate of 195.9 \pm 15.2 bites $\mathrm{m}^{-2}$ of live coral $\mathrm{h}^{-1}$. Rates of coral feeding were, however, spatially variable and ranged from 77 to 420 bites per quadrat. Overall, corallivorous wrasses took $74 \%$ (9312 bites) of all bites taken inside quadrats.

In terms of bites taken, L. unilineatus and C. baronessa were the predominant corallivores in the shallow zones, though feeding of both species declined with depth. Labrichthys unilineatus was unique in the widespread nature of its coral consumption, as bites were observed in $89 \%$ (57/64) of quadrats; furthermore, these seven quadrats with zero bites were all in the deepest zone $(10 \mathrm{~m})$. Labrichthys unilineatus fed most heavily on the reef flat with a feeding rate of $35 \cdot 3 \pm 2 \cdot 3$ bites per $\mathrm{m}^{-2}$ per $15 \mathrm{~min}$, just under twice that observed for $C$. baronessa $(19.2 \pm 2.8$ bites per $\mathrm{m}^{-2}$ per $15 \mathrm{~min}$ ), the second-heaviest feeder in this shallow zone [Fig. 1(b)].

In the deeper zones, other corallivorous species became more prevalent, especially D. xanthurus and L. alleni [Fig. 1(b)]. Diproctacanthus xanthurus was observed to feed across all depths, but feeding activity peaked $6 \mathrm{~m}$ below the crest with $13.8 \pm$ 2.4 bites per $\mathrm{m}^{-2}$ per $15 \mathrm{~min}$. Labropsis alleni was the most prevalent corallivore in the deeper zones $\left(16.8 \pm 2.3\right.$ bites per $\mathrm{m}^{-2}$ per $\left.15 \mathrm{~min}\right)$ and seldom fed in depths $<10 \mathrm{~m}$. In contrast to the tubelip wrasses, other corallivorous butterflyfishes (primarily $C$. octofasciatus and $C$. lunulatus) were always a minor contributor to corallivory, although the feeding rate of $C$. octofasciatus did increase slightly with depth. These other chaetodontids, even combined, rarely took $>30$ bites from within a quadrat.

\section{SPECIES-SPECIFIC DIET PATTERNS OF CORALLIVOROUS WRASSES}

In situ feeding observations confirmed that adult individuals of D. xanthurus, L. unilineatus and L. alleni feed almost exclusively from scleractinian corals, with at least $97 \%$ of bites occurring on live coral. In addition to hard corals, D. xanthurus and L. alleni also took a small proportion of their bites from non-coralline sources, mainly cleaning other reef fishes, although $L$. alleni also fed from sponges in small quantities ( $1.2 \%$ of bites).

The range and proportional consumption of different corals varied greatly among the three wrasses. Labropsis alleni was the most specialized of the three species, feeding from only 33 species of hard coral, and just over half of all bites were directed towards only two species, Pavona cactus (33.75\%) and Anacropora puertogalerae (21.8\%) (Fig. 2). Dietary overlap between L. alleni and other corallivorous wrasses was also very low: $T=0.25$ and 0.20 for D. xanthurus and L. unilineatus, respectively.

Diproctacanthus xanthurus and L. unilineatus had broad diets compared with L. alleni and consumed 46 and 53 coral species, respectively, and also exhibited a much higher dietary similarity $(T=0 \cdot 54)$. Corals of the genus Acropora accounted for just under half of all bites for both species (Fig. 2). Diproctacanthus xanthurus tended to actively forage across 26 different Acropora species, and never took $>6 \%$ of its bites from any one species. In contrast, L. unilineatus fed from 20 Acropora 

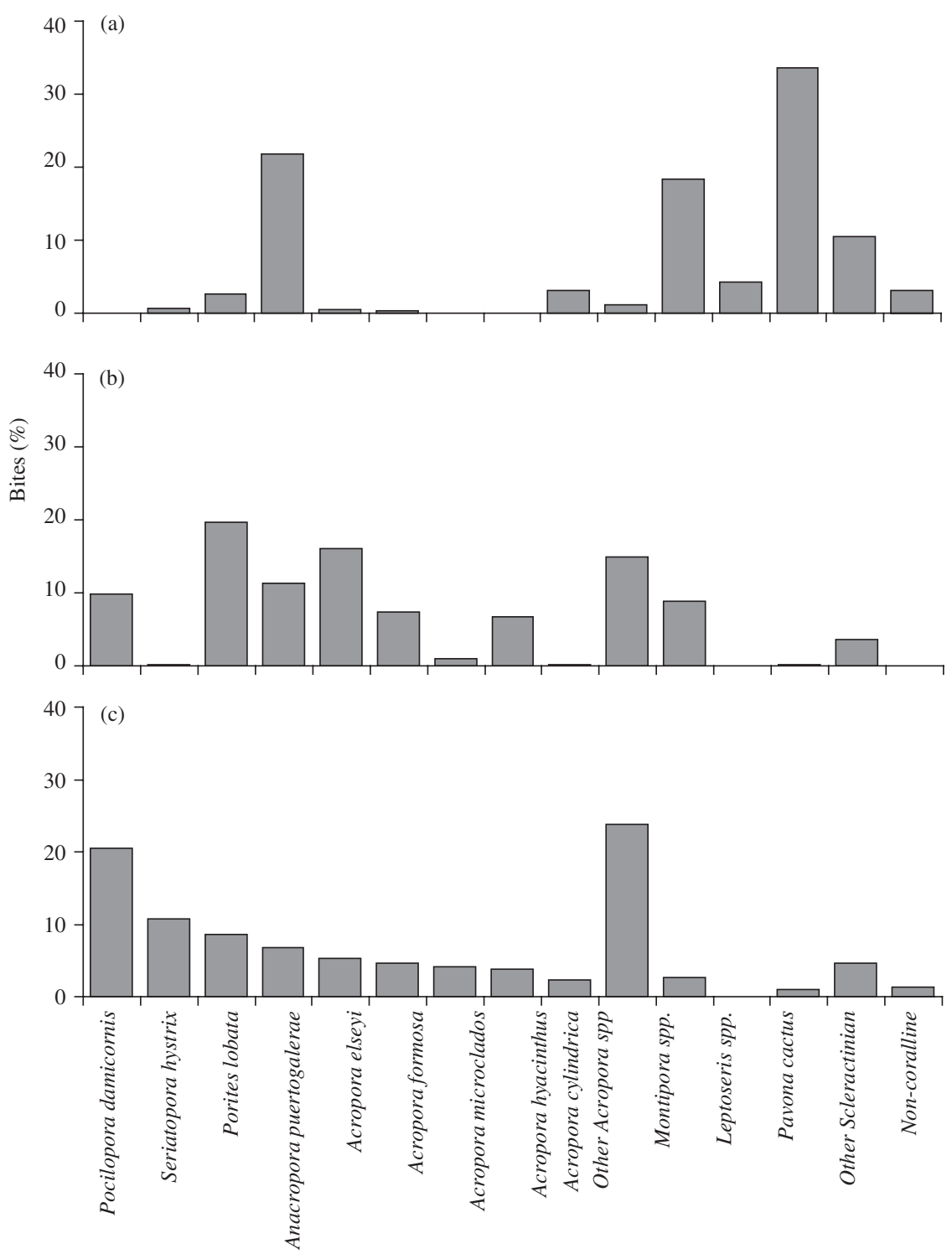

Coral species

FIG. 2. Per cent consumption of main coral prey for three species of corallivorous wrasse (a) Labropsis alleni (total bites = 2378), (b) Labrichthys unilineatus (total bites = 4577) and (c) Diproctacanthus xanthurus (total bites $=2708)$.

species; however, feeding was mainly concentrated on Acropora elseyi (16.1\%), Acropora formosa (7.4\%) and Acropora hyacinthus (6.6\%). Despite this similarity, the focal point of each wrasse's diet was very different. Labrichthys unilineatus fed most heavily from Porites lobata (19.8\%), while D. xanthurus primarily consumed P. damicornis (20.5\%) (Fig. 2). 
TABLE I. Dietary selectivity of coral-feeding wrasses. The significance of selectivity $(P)$ was ascertained by comparing overall levels of selectivity $\left(\chi^{2}{ }_{\mathrm{L} 2}\right)$ to a $\chi^{2}$ distribution with $n(I-1)$ d.f., where $I$ was the total number of prey types utilized by each species of wrasse

\begin{tabular}{lccc}
\hline Species & $n$ & $\chi^{2}{ }_{\mathrm{L} 2}$ & $P$ \\
\hline Labrichthys unilineatus & 21 & $1.79 \times 10^{3}$ & $<0.001$ \\
Diproctacanthus xanthurus & 12 & $2.68 \times 10^{3}$ & $<0.001$ \\
Labropsis alleni & 64 & $1.56 \times 10^{4}$ & $<0.001$ \\
\hline
\end{tabular}

The relative utilization of damaged coral by each species also differed dramatically. Labrichthys unilineatus fed heavily from damaged sections and took $25 \%$ of its bites from these areas. Furthermore, L. unilineatus incorporated damaged sections from all species fed from. In contrast, $D$. xanthurus and L. alleni were more likely to feed from healthy areas and only 6.4 and $7.0 \%$ of bites were taken from injured areas, respectively. When damaged coral was encountered, all three species increased feeding activity, although $L$. unilineatus was the only species that appeared to actively seek out damaged sections.

\section{PATTERNS OF CORAL SELECTIVITY}

All three species exhibited significant dietary selection and consumed one or more prey species in proportions greater than expected based on their availability (Table I). Diproctacanthus xanthurus and L. alleni showed the highest degree of selectivity, consuming preferred prey in much greater proportions than expected. Labropsis alleni tended to select for only a few coral species, principally P. cactus, Montipora species and, to a lesser extent, Leptoseris hawaiiensis (Fig. 3). In terms of selectivity, L. alleni was inclined to either select or avoid different coral species, and only A. puertogalerae was consumed in proportions similar to availability. Diproctacanthus xanthurus showed strong positive selection for A. millepora, Seriatopora hystrix and $P$. damicornis but avoided P. lobata, Montipora spp. and Acropora cyclindrica. Labrichthys unilineatus was much less selective. Some positive selection was exhibited for A. hyacinthus and P. lobata and, conversely, S. hystrix and A. millepora were avoided. Overall, L. unilineatus tended to feed from most species in proportions expected if feeding was largely non-selective (Fig. 3).

\section{DISCUSSION}

The present study showed that tubelip wrasses are the primary corallivores on near-shore reefs in Kimbe Bay. Tubelip wrasses were two and a half times more abundant and took three times as many bites on corals compared with coral-feeding butterflyfishes in this region. This was true across all depth gradients, although different tubelip wrasse species were prevalent at each depth. Even when taking into account the larger mean size of butterflyfishes, it appears likely that the total biomass of wrasses is higher. Subsequently, tubelip wrasses are a functionally important component of the corallivore guild in Kimbe Bay, Papua New Guinea. This study also confirmed that species from three different wrasse genera (D. xanthurus, 

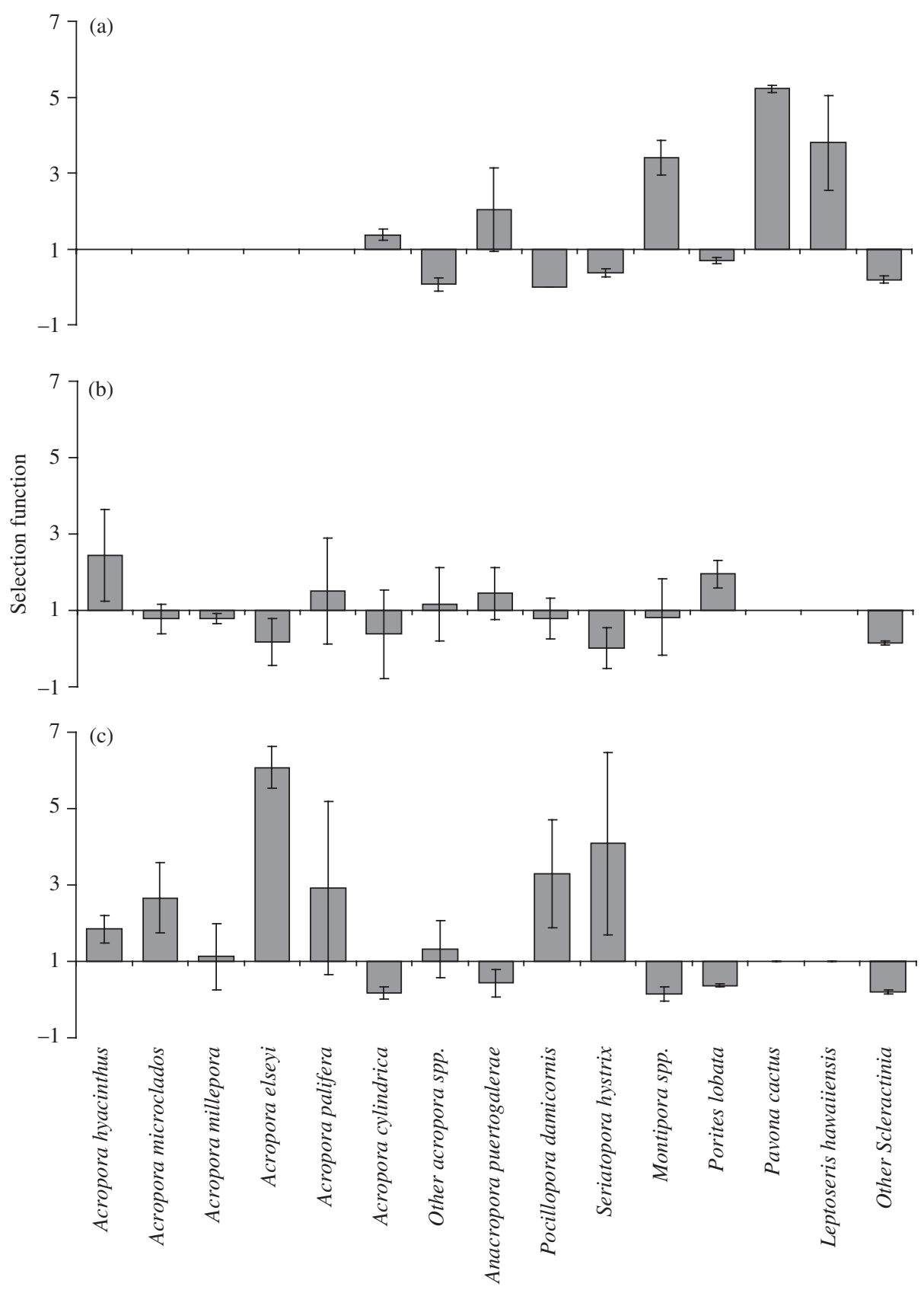

\section{Coral species}

FIG. 3. Dietary selection by coral-feeding wrasses. (a) Labropsis alleni, (b) Labrichthys unilineatus and (c) Diproctacanthus xanthurus. Values are means $\pm 95 \%$ CI. Selection functions $>1$ indicate that these corals were used more than expected from their availability (i.e. selected), while selection functions $<1$ indicate corals that were avoided. Gaps represent species that were not available to be grazed inside a species' feeding territory. 
L. unilineatus and L. alleni) are all obligate corallivores as adults. Fishes are considered obligate hard coral-feeders when $>80 \%$ of their bites are taken from living coral (Cole et al., 2008). At Kimbe Bay, adult tubelip wrasses took between 97 and 100\% of bites from scleractinian corals, and, as such, hard coral is clearly an important food resource. The extent of feeding selectivity and overlap among species, however, appears to differ from their more well-known butterflyfish counterparts.

Previous work has shown that obligate corallivorous butterflyfishes can be separated along a continuum from generalists to specialists (Birkeland \& Neudecker, 1981; Irons, 1989; Cox, 1994; Alwany et al., 2003; Pratchett, 2005, 2007; Berumen et al., 2005). Specialist feeders are capable of using only a very restricted range of prey species irrespective of abundance and are fundamentally dependent on these prey species for their survival (Irons, 1989; Berumen et al., 2005; Pratchett et al., 2006; Graham, 2007). Chaetodon trifascialis is the most specialized corallivorous butterflyfish, feeds almost exclusively on tabular Acropora colonies (Irons, 1989; Pratchett, 2005) and is among the most susceptible species to coral depletion (Reese, 1981; Pratchett et al., 2006; Wilson et al., 2006). In comparison, the three species of tubelip wrasse exhibit only minor to moderate levels of dietary specialization; all three species consumed at least 33 different coral species, and major dietary components never accounted for more than a third of their total diet.

Labropsis alleni is the most specialized of the three study species, taking a disproportionate number of bites from the relatively rare corals, P. cactus, Montipora species and L. hawaiiensis. Additionally, the dietary composition of L. alleni was very consistent among individuals, despite marked variation in the local abundances of different corals. These data suggest that L. alleni has strong and consistent preferences for the aforementioned corals. Diproctacanthus xanthurus also showed a moderate degree of dietary specialization and exhibited clear feeding preferences for Acropora species, P. damicornis and S. hystrix. Diproctacanthus xanthurus consumes a much wider range of corals compared with L. alleni and is capable of altering its diet in response to differences in coral abundances among feeding territories. For example, $P$. damicornis was abundant on the reef crest where it is grazed heavily but on the deeper slope feeding was often directed towards A. puertogalerae and staghorn Acropora which were the more abundant species at this depth. Of the three wrasse species, the diet composition of D. xanthurus was the most similar to that seen in butterflyfishes, with feeding preferences for Acropora and Pocilloporid corals (Pratchett, 2005, 2007; Berumen et al., 2005).

Generalist feeders typically show large variation in diet composition among individuals and between geographical areas (Birkeland \& Neudecker, 1981), reflecting variation in availability of different prey types. Labrichthys unilineatus was the least specialized of the three wrasses. This species showed little prey selectivity and fed on most corals in direct proportion to their availability. Labrichthys unilineatus is an obligate corallivore throughout its geographical range, although the corals eaten do vary (Sano et al., 1984; McIlwain \& Jones, 1997). At Lizard Island, L. unilineatus consumed predominantly A. hyacinthus and Montipora species, which were the most abundant coral species at this study site (McIlwain \& Jones, 1997). Similar patterns were observed at Kimbe Bay, where L. unilineatus fed predominantly on the most abundant coral species, P. lobata. Interestingly, in Kimbe Bay L. unilineatus consumed $P$. lobata disproportionately to its availability. These data suggest that L. unilineatus is a generalist feeder that specializes on locally abundant coral species. 
Specialization differences between corallivorous species have important consequences for the survival of these species following disturbance events and subsequent declines in live coral. Highly specialized species that rely on only a small sub-set of available resources (e.g. C. trifascialis) are prone to extinction following the loss of these key resources (Munday, 2004; Wilson et al., 2006; Munday et al., 2008; Pratchett et al., 2008). In contrast, coral-feeding generalists are more capable of adapting to changes in the coral community (Pratchett et al., 2004, 2006). Of all corallivorous fishes studied to date, L. unilineatus appears to be among the most resilient to changes in the coral community. This species is highly adaptable to differences in the coral community, both between regions and across the reef. This flexibility may partly explain its numerical dominance in Kimbe Bay. It is worth noting that even the most adaptable corallivorous species are still highly dependent on live corals (Pratchett et al., 2006). Even L. unilineatus has gone locally extinct in several regions following large scale declines in live coral cover following outbreaks of the crown-of-thorns starfish and mass bleaching events (Sano et al., 1987; Jones et al., 2004; Sano, 2004; Garpe et al., 2006; Graham, 2007).

The extent that the disturbance history of Kimbe Bay has influenced the outcome of this study is not known. The low abundance of corallivorous chaetodontids on the study reefs may reflect recent declines in live coral cover, attributable to dual impacts of climate-induced coral bleaching and persistently high levels of sedimentation (Jones et al., 2004). Between 1997 and 2002, coral cover in Kimbe Bay declined from $c .66 \%$ to $c .7 \%$. Branching Acropora species, which are the preferred prey of many corallivorous fishes (Pratchett, 2007), declined to $<2 \%$ cover on the crest of near-shore reefs (Jones et al., 2004). Abundances of all coral-feeding species were severely impacted, and while some recovery has occurred, densities of corallivores may not have returned to pre-impacted levels. Interestingly, this decline does not appear to have affected corallivorous wrasses to the same degree as chaetodontids. This may have occurred because corallivorous wrasses overall have a lower degree of specialization compared with corallivorous butterflyfishes and were able to adapt their diet to feed on previously unexploited coral species. This implies that generalist species such as L. unilineatus are more likely to survive long-term environmental changes.

Another explanation is that coral-feeding wrasses have a much higher recruitment rate, which may facilitate re-colonization following a major disturbance event. In general, larval butterflyfishes are poorly represented in the plankton (Leis, 1989). In a 2.5 year recruitment study, butterflyfishes were found to have some of the lowest recruitment rates on near-shore reefs in Kimbe Bay (Srinivasan \& Jones, 2006). In contrast, L. unilineatus had a much higher settlement rate, and this may explain the high abundance of this species relative to both other tubelip wrasses and butterflyfishes. In near-shore reefs of Kimbe Bay, the highly specialized butterflyfish $C$. trifascialis has still not recovered from the declines in coral cover despite recent increases in the abundance of its prey corals. It is possible that corallivorous wrasses, especially the generalist $L$. unilineatus, have partly succeeded corallivorous butterflyfishes in Kimbe Bay. If this is the case, it will have important ramifications for the community structure on future coral reefs, considering the expected regime of increased anthropogenic disturbances. These future coral reefs will probably select for generalist species that have a high flexibility in habitat and prey use. 
Labrichthys unilineatus could be further separated from other corallivorous wrasses and from chaetodontids based on the differences in foraging behaviour. The feeding behaviour of $D$. xanthurus and L. alleni was consistent with the feeding behaviour detailed by Tricas (1989) for the coral-feeding Multiband butterflyfish Chaetodon multicinctus Garrett. Specifically, corals are encountered and then carefully inspected before feeding. Bites on corals are then divided into distinct feeding forays, often comprising multiple bites within any one region of the coral, interspersed with movement to a new part of the coral or an alternative colony (Tricas, 1989). In contrast, L. unilineatus rapidly and consistently bites the same exact area of a coral colony and displays little evidence of colony inspection between bites or feeding forays. These differences in foraging behaviour may reflect highly contrasting feeding strategies, whereby the former species feed predominantly on coral tissue (more specifically, exposed tentacles of individual coral polyps), whereas the latter species (L. unilineatus) is targeting coral mucus.

Tricas (1989) explains the distinctive feeding behaviour of $C$. multicinctus, which searches the surface of corals between every bite and rarely takes more than a few bites in any one location, in terms of polyp feeding and the retraction of coral polyps. It is likely, therefore, that D. xanthurus and L. alleni are also searching for specific locations within each coral colony where polyps are extended and are then required to move to an entirely new feeding location. Repeated feeding in the same location must be delayed long enough for polyps to once again become fully extended (Gochfeld, 2004).

Most corallivorous fishes are thought to target coral polyps and thus exhibit highly convergent feeding preferences, leading to the assumption that polyps are the most nutritious component of hard corals. Coral mucus contains a large protein-nitrogen component that results in a carbon to nitrogen ratio comparable with coral tissue (Brown \& Bythell, 2005). Additionally, major lipid components of coral mucus are wax esters (particularly cetyl palmitate) and triglycerides. These compounds make coral mucus a relatively rich energy source for those species capable of digesting them (Benson \& Muscatine, 1974). Corallivorous fishes have some of the longest intestines of all fishes, particularly mucous feeders (Harmelin-Vivien \& Bouchon-Navaro, 1983; Motta, 1988; Elliott \& Bellwood, 2003); long digestive tracts facilitate high gut retention times and may allow the digestion of these complex wax esters.

The relative use of damaged $v$. healthy corals may also be explained by coral mucus. Labrichthys unilineatus shows a consistent preference for both natural and experimentally damaged coral (McIlwain \& Jones, 1997). Corals that are broken, diseased or undergoing partial mortality are under considerable stress. A common stress response by corals is to increase mucous production (Loya \& Rinkevich, 1980; Krupp, 1984; Telesnicki \& Goldberg, 1995; Wild et al., 2004, 2005). Therefore, by targeting these damaged areas, L. unilineatus is most probably focusing on areas that have the highest availability of mucus. This idea is consistent with the lower relative use of damaged corals by $D$. xanthurus and L. alleni, which appear to predominantly feed on polyps. This is not to completely discredit the possibility that L. alleni and D. xanthurus feed on mucus in addition to coral polyps. Feeding intensity of these two species did increase when damaged colonies were encountered; however, the proportion of time spent foraging on damaged areas was considerably lower than that of L. unilineatus. 
The importance of corallivory as a functional group in coral reef dynamics has traditionally been underestimated (Robertson, 1970; Connell, 1973; Hatcher, 1988). Considering the high number of bites taken $\left(c .200 \mathrm{~m}^{2}\right.$ of live coral $\left.\mathrm{h}^{-1}\right)$ by coralfeeding fishes in this study, the transfer of energy up in the food web is likely to be considerable. For example, Glynn (2004) found over 287 links between corals, invertebrate and fish corallivores, and top-level fish predators on low-diversity eastern Pacific Ocean reefs. On higher diversity reefs (e.g. Kimbe Bay), the size and number of these links are expected to be even greater.

Tubelip wrasses (Diproctacanthus, Larabicus, Labrichthys and Labropsis) are a major group of corallivorous fishes on coral reefs, second only to butterflyfishes (Cole et al., 2008). In addition to the three species considered here, there are at least six other species of tubelip wrasses (Parenti \& Randall, 2000) that remain unstudied, although a similar reliance upon hard coral is expected (Lieske \& Myers, 2001; Randall, 2005; Froese \& Pauly, 2008). The three corallivorous wrasse species investigated in this study are all obligate corallivores as adults and consume a diverse range of coral species. Furthermore, the feeding modes also differed between the three species; L. alleni and D. xanthurus appear to predominantly target coral polyps and feed in a manner similar to the majority of corallivorous butterflyfishes. In contrast, L. unilineatus appears to partition the coral resource on a finer scale and feeds directly from coral mucus. Interspecific variation in prey selectivity among corallivorous wrasses has consequences for explaining both the distribution and abundance of their spatial patterns, and their resilience to disturbance events and declining coral cover. Corallivorous wrasses, as a group, show a broader dietary niche and greater flexibility than the more specialized corallivorous butterflyfishes; however, the ecological role of corallivorous wrasses is probably comparable with that played by butterflyfishes. The ecological effect that the corallivorous functional group has on the coral community is not well understood. Future research needs to focus on a functional group approach and consider the effect that chronic predation by corallivorous fishes as a guild has on the coral community and subsequently coral reef dynamics. Specific areas of future study include the effect of predation on a coral colony's energy budget, its capacity for repair and reproductive output. Further study is needed to ascertain how chronic predation by corallivorous fishes will interact with other anthropogenic stressors to influence the long-term survivorship of coral reef communities.

We thank the Mahonia Na Dari Research and Conservation Centre and the traditional owners of the Tamare and Kilu reefs, for allowing us access. We are also indebted to T. Petray and B. Uma for field assistance, and comments from two reviewers greatly improved this manuscript. Funding was provided by the ARC Centre of Excellence for Coral Reef Studies. This study complies with Papua New Guinean laws.

\section{References}

Aeby, G. S. (2002). Trade-offs for the butterflyfish, Chaetodon multicinctus, when feeding on coral prey infected with trematode metacercariae. Behavioural Ecology and Sociobiology 52, 158-165.

Allen, G. R. \& Munday, P. L. (1994). Kimbe Bay Rapid Ecological Assessment: The Coral Reefs of Kimbe Bay (West New Britain, Papua New Guinea), Vol. 3. Auckland, New Zealand: The Nature Conservancy. 
Alwany, M. Thaler, E. \& Stachowitsch, M. (2003). Food selection in two corallivorous butterflyfishes, Chaetodon austriacus and C. trifascialis, in the northern Red Sea. Marine Ecology 24, 165-177.

Bellwood, D. R. (1996). Production and reworking of sediment by parrotfishes (family Scaridae) on the Great Barrier Reef, Australia. Marine Biology 125, 795-800.

Bellwood, D. R. \& Choat, J. H. (1990). A functional-analysis of grazing in parrotfishes (family Scaridae) - the ecological implications. Environmental Biology of Fishes 28, $189-214$.

Benson, A. A. \& Muscatine, L. (1974). Wax in coral mucus: energy transfer from corals to reef fishes. Limnology and Oceanography 19, 810-814.

Berumen, M. L., Pratchett, M. S. \& McCormick, M. I. (2005). Within-reef differences in diet and body condition of coral-feeding butterflyfishes (Chaetodontidae). Marine Ecology Progress Series 287, 217-225.

Birkeland, C. \& Neudecker, S. (1981). Foraging behaviour of two Caribbean Chaetodontids: Chaetodon capistratus and C. aculeatus. Copeia 1981, 169-178.

Brown, B. E. \& Bythell, J. C. (2005). Perspectives on mucus secretion in reef corals. Marine Ecology Progress Series 296, 291-309.

Ceccarelli, D. (2007). Modification of benthic communities by territorial damselfish: a multispecies comparison. Coral Reefs 26, 853-866.

Cole, A. J. (2007). Dietary composition and feeding behaviour of tubelip wrasses: importance and consequences of corallivory Marine Biology. Honows Thesis, James Cook University, Townsville, Australia.

Cole, A. J., Pratchett, M. S. \& Jones, G. P. (2008). Diversity and functional importance of coral-feeding fishes on tropical coral reefs. Fish and Fisheries 9, 1-22.

Connell, J. H. (1973). Population ecology of reef building Corals. In Biology and Geology of Coral Reefs (Jones, O. A. \& Endean, R., eds), pp. 247-268. New York, NY: Academic Press.

Cox, E. F. (1986). The effects of a selective corallivore on growth rates and competition for space between two species of Hawaiian corals. Journal of Experimental Marine Biology and Ecology 101, 161-174.

Cox, E. F. (1994). Resource use by corallivorous butterflyfishes (Family Chaetodontidae) in Hawaii. Bulletin of Marine Science 54, 535-545.

Elliott, J. P. \& Bellwood, D. R. (2003). Alimentary tract morphology and diet in three coral reef fish families. Journal of Fish Biology 63, 1598-1609.

Feary, D. A. (2007). The influence of resource specialization on the response of reef fish to coral disturbance. Marine Biology 153, 153-161.

Fox, R. J. \& Bellwood, D. R. (2007). Quantifying herbivory across a coral reef depth gradient. Marine Ecology Progress Series 339, 49-59.

Gardiner, N. M. \& Jones, G. P. (2005). Habitat specialisation and overlap in a guild of coral reef cardinalfishes (Apogonidae). Marine Ecology Progress Series 305, 163-175.

Garpe, K. C., Yahya, S. A. S., Lindahl, U. \& Öhman, M. C. (2006). Long-term effects of the 1998 coral bleaching event on reef fish assemblages. Marine Ecology Progress Series 315, 237-247.

Glynn, P. W. (2004). High complexity food webs in low-diversity eastern Pacific reef-coral communities. Ecosystems 7, 358-367.

Gochfeld, D. J. (2004). Predation-induced morphological and behavioral defenses in a hard coral: implications for foraging behavior of coral-feeding butterflyfishes. Marine Ecology Progress Series 267, 145-158.

Gore, M. A. (1984). Factors affecting the feeding behavior of a coral reef fish, Chaetodon capistratus. Bulletin of Marine Science 35, 211-220.

Graham, N. A. (2007). Ecological versatility and the decline of coral feeding fishes following climate driven coral mortality. Marine Biology 153, 119-127.

Graham, N. A., Wilson, S. K., Jennings, S., Polunin, N. V. C., Bijoux, J. P. \& Robinson, J. (2006). Dynamic fragility of oceanic coral reef ecosystems. Proceedings of the National Academy of Sciences of the United States of America 103, 8425-8429.

Graham, N. A. J., Wilson, S. K., Pratchett, M. S., Polunin, N. V. C. \& Spalding, M. D. (2009). Coral mortality versus structural collapse as drivers of corallivorous butterflyfish decline. Biodiversity Conservation 18, 3325-3336. doi: 10.1007/s10531-009-9633-3 
Halford, A., Cheal, A. J., Ryan, D. \& Williams, D. M. (2004). Resilience to large-scale disturbance in coral and fish assemblages on the Great Barrier Reef. Ecology 85, $1892-1905$.

Harmelin-Vivien, M. L. \& Bouchon-Navaro, Y. (1983). Feeding diets and significance of coral feeding among Chaetodontid fishes in Moorea (French Polynesia). Coral Reefs 2, 119-127.

Hatcher, B. G. (1988). Coral reef primary productivity: a beggar's banquet. Trends in Ecology and Evolution 3, 106-111.

Hoey, A. S. \& Bellwood, D. R. (2008). Cross-shelf variation in the role of parrotfishes on the Great Barrier Reef. Coral Reefs 27, 37-47.

Holthus, P. (1994). Kimbe Bay Rapid Ecological Assessment, Vol. 1. Auckland, New Zealand: The Nature Conservancy.

Holthus, P. \& Maragos, J. (1994). Kimbe Bay Rapid Ecological Assessment, Vol. 2. Auckland, New Zealand: The Nature Conservancy.

Irons, D. K. (1989). Temporal and areal feeding behavior of the butterflyfish, Chaetodon trifiscialis, at Johnston Atoll. Environmental Biology of Fishes 25, 187-193.

Jones, G. P. (1992). Interactions between herbivorous fishes and macro-algae on temerate rocky reefs. Journal of Experimental Marine Biology and Ecology 159, 217-235.

Jones, G. P., McCormick, M. I., Srinivasan, M. \& Eagle, J. V. (2004). Coral decline threatens fish biodiversity in marine reserves. Proceedings of the National Academy of Sciences of the United States of America 101, 8251-8253.

Khalaf, M. A. \& Abdallah, M. (2005). Community structure of butterflyfishes in the Red Sea and Gulf of Aden. Aquatic Conservation-Marine and Freshwater Ecosystems 15, S77-S89.

Kokita, T. \& Nakazono, A. (2001). Rapid response of an obligately corallivorous filefish Oxymonacanthus longirostris (Monacanthidae) to a mass coral bleaching event. Coral Reefs 20, 155-158.

Krupp, D. A. (1984). Mucus production by corals exposed during an extreme low tide. Pacific Science 38, 1-11.

Leis, J. M. (1989). Larval biology of butterflyfishes (Pisces, Chaetodontidae) - what do we really know. Environmental Biology of Fishes 25, 87-100.

Lieske, E. \& Myers, R. (2001). Coral Reef Fishes: Indo-Pacific and Caribbean. Milan: Harper Collins Publishers.

Loya, Y. \& Rinkevich, B. (1980). Effects of oil pollution on coral reef communities. Marine Ecology Progress Series 3, 167-180.

Manly, B. F. J., McDonald, L. L. \& Thomas, D. L. (1993). Resource Selection Functions by Animals. London: Chapman \& Hall.

McIlwain, J. L. \& Jones, G. P. (1997). Prey selection by an obligate coral-feeding wrasse and its response to small-scale disturbance. Marine Ecology Progress Series 155, 189-198.

Morrison, D. (1988). Comparing fish and urchin grazing in shallow and deeper coral reef algal communities. Ecology 69, 1367-1382.

Motta, P. J. (1988). Functional morphology of the feeding apparatus of ten species of Pacific butterflyfishes (Perciformes, Chaetodontidae): an ecomorphological approach. Environmental Biology of Fishes 22, 39-67.

Munday, P. L. (2004). Habitat loss, resource specialization, and extinction on coral reefs. Global Change Biology 10, 1642-1647.

Munday, P. L., Jones, G. P., Pratchett, M. S. \& Williams, A. J. (2008). Climate change and the future for coral reef fishes. Fish and Fisheries 9, 1-25.

Nadon, M. \& Stirling, G. (2006). Field and simulation analyses of visual methods for sampling coral cover. Coral Reefs 25,177-185.

Neudecker, S. (1977). Transplant experiments to test the effect of fish grazing on coral distribution. In Proceedings of the 3rd International Coral Reef Symposium (Taylor, D. L., ed.), pp. 317-323. Miami, FL: School of Atmospheric and Marice Sciences, University of Miami.

Neudecker, S. (1979). Effects of grazing and browsing fishes on the zonation of corals in Guam. Ecology 60, 666-672.

Parenti, P. \& Randall, J. E. (2000). An annotated checklist of the species of the labroid fish families Labridae and Scaridae. Ichthyological Bulletin 68, 1-97. 
Pratchett, M. S. (2005). Dietary overlap among coral-feeding butterflyfishes (Chaetodontidae) at Lizard Island, northern Great Barrier Reef. Marine Biology 148, 373-382.

Pratchett, M. S. (2007). Dietary selection by coral-feeding butterflyfishes (Chaetodontidae) on the Great Barrier Reef, Australia. Raffles Bulletin of Zoology S14, 155-160.

Pratchett, M. S. \& Berumen, M. L. (2008). Inter-specific variation in distributions and diets of coral reef butterflyfishes (Teleostei: Chaetodontidae). Journal of Fish Biology 73, $1730-1747$.

Pratchett, M. S., Wilson, S. K., Berumen, M. L. \& McCormick, M. I. (2004). Sublethal effects of coral bleaching on an obligate coral feeding butterflyfish. Coral Reefs 23, $352-356$.

Pratchett, M. S., Wilson, S. K. \& Baird, A. H. (2006). Declines in the abundance of Chaetodon butterflyfishes following extensive coral depletion. Journal of Fish Biology 69, $1269-1280$.

Pratchett, M. S., Munday, P. L., Wilson, S. K., Graham, N. A., Cinner, J. E., Bellwood, D. R., Jones, G. P., Polunin, N. V. C. \& McClanahan, T. R. (2008). Effects of climateinduced coral bleaching on coral-reef fishes - ecological and economic consequences. Oceanography and Marine Biology Annual Review 46, 251-296.

Randall, J. E. (1974). The effect of fishes on coral reefs. In Proceedings of the 2nd International Coral Reef Symposium (Cameron, A. M., Campbell, A. B., Cribb, R., Endean, J. S., Jell, O. A., Jones, P., Mather, P. \& Talbot, F. H., eds), pp. 159-166. Brisbane, Australia: Great Barrier Reef Committee.

Randall, J. E. (2005). Reef and Shore Fishes of the South Pacific: New Caledonia to Tahiti and the Pitcairn Islands. Honolulu, HI: University of Hawai'i Press.

Reese, E. S. (1977). Coevolution of corals and coral feeding fishes of the family Chaetodontidae. In Proceedings of the 3rd International Coral Reef Symposium (Taylor, D. L., ed.), pp. 268-274. Miami, FL: School of Atmosphere and Marine Sciences, University of Miami.

Reese, E. S. (1981). Predation on corals by fishes of the family Chaetodontidae: implications for conservation and management of coral reef ecosystems. Bulletin of Marine Science 31, 594-604.

Robertson, D. R. (1970). Review of the predators and parasites of stony corals with special reference to symbiotic proso-branch gastropods. Pacific Science $\mathbf{2 4 ,}$ 43-54.

Ross, S. T. (1986). Resource partitioning in fish assemblages: a review of field studies. Copeia 1986, $352-388$.

Rotjan, R. D. \& Lewis, S. M. (2006). Parrotfish abundance and selective corallivory on a Belizean coral reef. Journal of Experimental Marine Biology and Ecology 335, $292-301$.

Rotjan, R. D. \& Lewis, S. M. (2008). Impact of coral predators on tropical reefs. Marine Ecology Progress Series 367, 73-91.

Rotjan, R. D., Dimond, J. L., Thornhill, D. J., Leichter, J. J., Helmuth, B., Kemp, D. W. \& Lewis, S. M. (2006). Chronic parrotfish grazing impedes coral recovery after bleaching. Coral Reefs 25, 361-368.

Sano, M. (2004). Short-term effects of a mass coral bleaching event on a reef fish assemblage at Iriomote Island, Japan. Fisheries Science 70, 41-46.

Sano, M., Shimizu, M. \& Nose, Y. (1984). Food habits of teleostean reef fishes in Okinawa Islands, southern Japan. University Museum University of Tokyo Bulletin 25, 1-128.

Sano, M., Shimizu, M. \& Nose, Y. (1987). Long-term effects of destruction of hermatypic corals by Acanthaster planci infestation on reef fish communities at Iromote Island, Japan. Marine Ecology Progress Series 37, 191-199.

Srinivasan, M. \& Jones, G. P. (2006). Extended breeding and recruitment periods of fishes on a low latitude coral reef. Coral Reefs 25, 673-682.

Telesnicki, G. \& Goldberg, W. (1995). Effects of turbidity on the photosynthesis and respiration of 2 South Florida reef coral species. Bulletin of Marine Science 57, 527-539.

Tricas, T. C. (1989). Prey selection by coral-feeding butterflyfishes: strategies to maximize the profit. Environmental Biology of Fishes 25, 171-185.

Wellington, G. M. (1982). Depth zonation of corals in the Gulf-of-Panama - control and facilitation by resident reef fishes. Ecological Monographs 52, 223-241. 
Wild, C., Huettel, M., Klueter, A., Kremb, S. G., Rasheed, M. Y. M. \& Jergensen, B. B. (2004). Coral mucus functions as an energy carrier and particle trap in the reef ecosystem. Nature 428, 66-70.

Wild, C., Woyt, H. \& Huettel, M. (2005). Influence of coral mucus on nutrient fluxes in carbonate sands. Marine Ecology Progress Series 287, 87-98.

Wilson, S. K., Graham, N. A., Pratchett, M. S., Jones, G. P. \& Polunin, N. V. C. (2006). Multiple disturbances and the global degradation of coral reefs: are reef fishes at risk or resilient? Global Change Biology 12, 2220-2234.

\section{Electronic Reference}

Froese, R. \& Pauly, D. (2008). FishBase. Available at www.fishbase.org 